\title{
Pressurized-Canister Trunk Injection of Acephate, and Changes in Abundance of Red Elm Bark Weevil (Magdalis armicollis) on American Elm (Ulmus americana)
}

\author{
Michael Booth and Dan Johnson
}

\begin{abstract}
Portable pressurized injection vials (Ecoject System) were used in an experiment to assess injection of acephate into elm trees (Ulmus americana) as a means of reducing within-tree abundance of red elm bark weevil (REBW), Magdalis armicollis. A total of $25 \mathrm{elm}$ trees were treated, each paired with an untreated tree. A total of 400 pressurized canisters were used in the study. REBW population density, as indicated by sticky-paper trap catches, on treated and untreated trees did not differ significantly at the time of trunk injection. Two weeks after injection, the average REBW trap catch on the 25 untreated trees had increased, whereas the average trap catch on the 25 treated trees had decreased. The resulting average trap catch from the treated trees was significantly lower than that of the control trees. Although subsequent declines in REBW populations precluded a longer record of the effects of tree injection, the significant reductions apparent in the first two weeks following injection indicated the method was effective in reducing REBW abundance. The impact on REBW populations was detectable even though treated and untreated trees were contiguous, indicating that selective treatment of individual trees could be part of an effective operational treatment for REBW management. No phytotoxic effects were detected by spectrophotometric assessment of leaf chlorophyll.

Key Words. Acephate; American elm; Canadian Prairies; Chlorophyll; Ecoject; Magdalis armicollis; Population Reduction; Red Elm Bark Weevil; Spectrophotometric; Sticky Trap Sampling; Trunk Injections; Ulmus americana; .
\end{abstract}

Elm trees (Ulmus americana) are highly valued on the Canadian Prairies and Northern Great Plains, for reasons of aesthetics, longevity, and ecological services. The mature elm population is in decline, accentuating perceived value and need for protection. Red elm bark weevil (REBW), Magdalis armicollis, is a potentially serious pest of elm trees in grassland and parkland regions of western Canada and the United States. REBW eggs are laid beneath the bark, and larval and pupal stages develop in situ. Adults emerge from bark the following year, and feed on growing leaves, resulting in typical shothole defoliation. Populations of REBW tend to increase in years with warm summers (M. Booth, unpublished observations, 1986-2007), and may also increase under drought stress (Saunders et al. 2004). Risk of REBW damage to elms is not a new problem in North America. Tucker (1907) described elm trees that were killed by the larvae boring into branches and trunks, and concluded that destruction of the afflicted trees was the only way to prevent more extensive infestations; this given the lack of control agents available in the early 20th Century.

More recently, foliar spray application, drench application, banding or paint-on applications (Doughty et al. 1992), and soil injection of insecticides have shown to be effective control methods for other pests of urban trees. Unintended offtarget movement of pesticides may pose potential risks to nontarget organisms (including natural enemies of pests), soil, and water. Trunk injection of insecticides has shown to be an effective method of controlling insect pests of trees and shrubs (Gill et al. 1999; Tipping and Center 2002; Young 2002; Doccoloa et al. 2003). Injection has potential for limiting other boring or bark-infesting insect pests of ornamental trees, such as elm bark beetle, emerald ash borer, lilac borer, western ash bark beetle, and other pests that feed within plant tissue.

General monitoring of REBW infestations on Government of Canada property was conducted during 1986-2006 (M. Booth, unpublished observations at Lethbridge Research Center). During May to August 2006, an experiment was conducted to evaluate the effects of trunk injection of pressurized liquid formulation of acephate (Orthene) on abundance of red elm bark weevil in American elm in Alberta, Canada. Previous tests by the Canadian Forest Service indicated potential effectiveness of the Ecoject injection system developed by BioForest Technologies Inc. (Sault Ste. Marie, ON, Canada). The Ecoject injection tool pressurizes small plastic vials, which inject small quantities of insecticide into the tree when they are inserted into holes drilled into the trunk.

\section{MATERIALS AND METHODS}

\section{Experimental Design}

\section{Randomization and Replication}

The experimental units in the trial consisted of 50 mature American elm trees. Treatment was randomly assigned to one tree in each of 25 contiguous pairs, so that each of the 25 randomized blocks of the experiment consisted of two mature American elm trees, standing together on the same side of a paved lane. The lane is on federally owned and managed research property near Highway 3, east of Lethbridge, Alberta, Canada. One reason for using a paired-tree randomized block design was to deter- 
mine whether a reduction in REBW numbers could be effected in a situation where injected trees were next to uninjected trees.

\section{Injection Treatment}

The Pest Management Regulatory Agency (PMRA, Health Canada) granted authorization to utilize a $97 \%$ dry flowable (DF) formulation (Arysta LifeScience) for this test, under the national "Risk Reduction Initiative" in support of pest management experimentation and refinement. The target injection application rate was determined according to circumference at breast height (cbh), $0.3 \mathrm{~g}$ ai / $\mathrm{cm}$ cbh ( $1.5 \mathrm{~g}$ ai / injector / 6 in cbh). Trees were measured and assigned a number of injectors based on tree size: one 8 $\mathrm{mL}(0.27 \mathrm{fl} \mathrm{oz})$ injector canister per $15 \mathrm{~cm}(6 \mathrm{in})$ trunk circumference. The number of injectors selected, determined at the time of treatment by dividing the tree circumference in $\mathrm{cm}$ by 15 ( $\mathrm{cbh}$ in inches divided by six), ranged from 12 to 22 injectors canisters per tree. Injector canisters were pressurized with the Ecoject System and then inserted into holes (one per canister) drilled near the base of the trees, $1.3-1.9 \mathrm{~cm}(0.5-0.75 \mathrm{in})$ into the cambium. The injector pressure for this method is approximately $0.379 \mathrm{MPa}(55$ psi) at the start of the loading stroke, and $0.448 \mathrm{MPa}(65 \mathrm{psi})$ at the end of the stroke. The nozzle size was $5.6 \mathrm{~mm}$ (7/32 in). Injectors typically delivered all of the formulated product into the tree within $10 \mathrm{~s}$. The injection procedure was completed on June 6, 2006.

\section{Sampling}

\section{Foliage}

Two branches of at least 8 leaves were collected from each tree on two sampling dates: immediately following the day of injection, and 8 weeks later (August 2, 2006) for chlorophyll analysis. Chlorophyll content has been used in previous studies as an indicator of chemical challenge and resulting tissue damage (Knudson et al. 1977), or pest feeding damage (Johnson 1983). In the current REBW study, elm leaves were removed, frozen, and returned to the grassland ecosystem laboratory at the University of Lethbridge (Alberta, Canada). Leaves were kept frozen until being dried and powdered. A sample of $1.0 \mathrm{~g}$ from each branch sample was extracted with $80 \%$ acetone and water in a liquid grinder/mixer. Absorbance was measured using a Biochrom Ultrospec 3300 pro UV/Visible spectrophotometer, and recorded between 300 and $800 \mathrm{~nm}$ for every sample; data at 664, $652,645,456$, and $432 \mathrm{~nm}$ were saved for statistical analysis. On August 23, 2006, the trees in the experiment were photographed to give additional general information on leaf condition.

\section{Insects}

Five yellow "Tanglefoot" sticky traps $[10.2 \times 15.2 \mathrm{~cm}(4 \times 6$ in)] were placed in each tree canopy. A total of 250 traps were placed at the beginning of each sampling period, and then removed and returned to the lab for counting of adult REBW under stereomicroscopes, to estimate changes in abundance. Sampling periods were $0,2,4,6$, and 8 weeks following treatment.

Relative humidity and ambient temperatures within the canopy and branch tissue were monitored during the experiment with HOBO data recorders (Onset Computer Corp., Bourne, MA) and Oakton temperature recorders in the canopy of one of the trees. General weather data for the site was provided by a permanent weather station within $1 \mathrm{~km}(0.62 \mathrm{mi})$, at the Agriculture and Agri-Food Canada Research Centre.

\section{RESULTS AND DISCUSSION}

\section{Tree Measurements}

Circumference at breast height of the 50 trees used in the experiment ranged between 135 and $361 \mathrm{~cm}(53-142$ in), mean $=96.8$ $\mathrm{cm}$ (38.1 in), $\mathrm{SEM}=2.73 \mathrm{~cm}$ (6.9 in) (good fit to a normal distribution; G.O.F. Shapiro-Wilk Test, $\mathrm{W}=0.9808, P>0.5$, SAS Institute, 2007). The 25 trees assigned to the control did not differ in average size from the 25 trees assigned to the treatment $(\mathrm{t}=0.304$, $P>0.5$; this confirmed there was no initial bias in trunk size).

\section{Chlorophyll Content}

Chlorophyll content (and related variables affecting leaf color), as represented by spectrophotometric absorbance at 664 , $652,645,456$, or $432 \mathrm{~nm}$, did not differ between treatments (injected versus noninjected) either at the time of treatment application, or 8 weeks after injection (Figure 1, ANOVA, $P$ $>0.3$ ), for all five measured wavelengths. An example plot of the absorbance spectrum for one sample is shown in Figure 2.

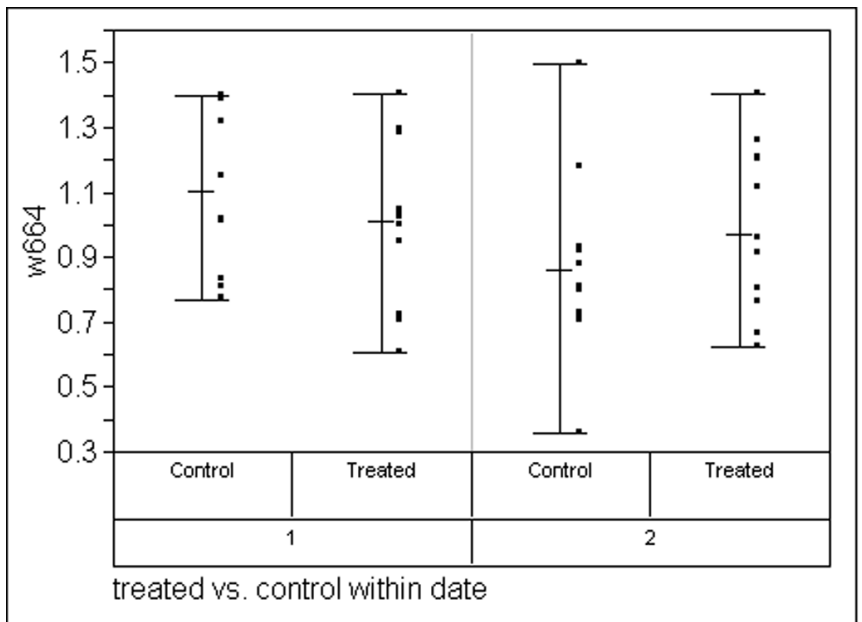

Figure 1. Relative absorbance at $664 \mathrm{~nm}$, for leaves from control versus treated trees, at the time of injection (date 1) or 8 weeks later (date 2).

\section{Insect Sampling and Population Estimates}

Of the total 500 sticky traps that were attached in the canopies of the 50 trees for the first two sampling periods, 18 and 55 (respectively) were lost because of wind, but losses were approximately equal for treated and untreated trees. The resulting counts ranged typically between 0 and 5 adult beetles per sticky trap card. The counts were log-transformed before statistical analysis: $\ln (\mathrm{REBW}+0.5)$. Tree size was not a significant covariate in the analysis of covariance, and did not alter the effectiveness of injection as indicated by REBW counts. REBW populations on the 25 treated and 25 untreated trees did not differ significantly at the time of injections (Table 1; ANOVA on log-transformed REBW counts, $P=0.41$ ). By two weeks after injection, the average REBW densities on the untreated trees had increased, whereas the densities on the treated trees had decreased (Table 1). At that time, the average count on traps from the treated trees was significantly lower than in the control group (ANOVA on log-transformed REBW counts, $P=0.0245$ ). 


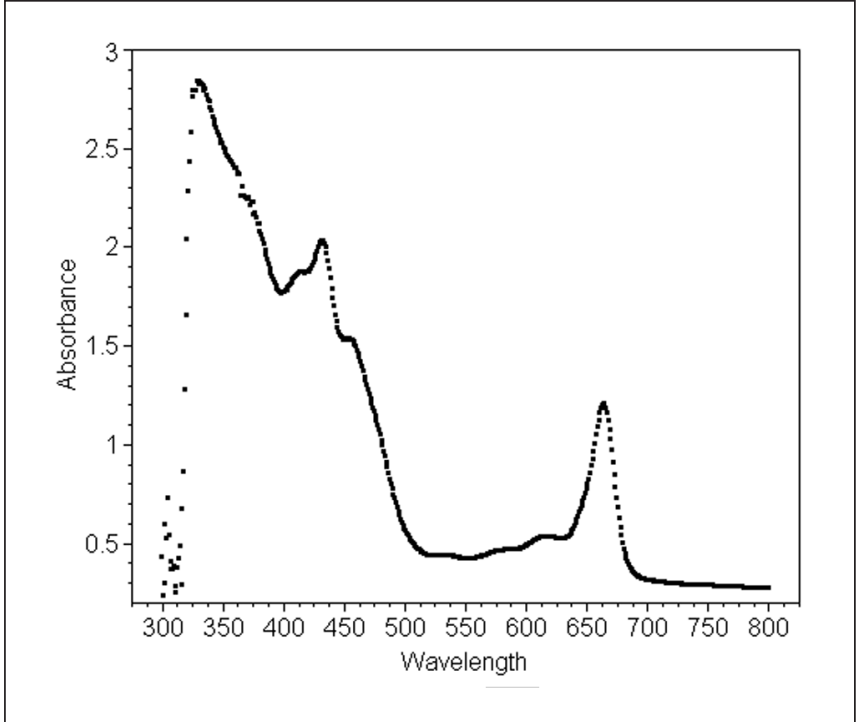

Figure 2. Typical absorbance spectrum (Biochrom Ultrospec 3300 pro UV/Visible spectrophotometer) for one elm leaf sample (tree 7, date 2).

On later dates, the populations of all blocks and both treatments declined, resulting in more frequent "zero" counts and treatment differences were no longer measurable after that time. The sampling scheme in our experiment did not distinguish between mortality and possible consequence of repellency.

\section{Relative Population Changes}

The more rapid drop in the REBW counts on the treated trees $(\mathrm{T})$, with respect to that of the untreated control trees (C), during the first two weeks after injection, resulted in a decline in abundance of $36.7 \%$ on the treated trees, adjusted against the change on the control trees. This is an adjusted value (Abbott 1925), calculated as $100 *(1$ - odds ratio), where the odds ratio is $\left(\mathrm{T}_{2} * \mathrm{C}_{1}\right) /\left(\mathrm{T}_{1} * \mathrm{C}_{2}\right)$. This measure has been shown to be a reliable indicator of adjusted changes in pest abundance (often interpreted as mortality), applicable to randomized complete block designs sampled over time in field studies, such as this, and confirmed in Monte Carlo simulation studies (Schaalje et al. 1986).

Table 1. Numbers of valid (not blown down by wind) sticky traps, and mean numbers of REBW per trap, during the first two weeks following injection.

a. At the time of injection

\begin{tabular}{llll}
\hline & $\mathrm{n}$ & mean & SEM \\
\hline treated & 116 & 0.3103 & 0.05254 \\
control & 116 & 0.4138 & 0.06825 \\
\hline
\end{tabular}

b. Two weeks post-treatment

\begin{tabular}{lrrl}
\hline & $\mathrm{n}$ & mean & SEM \\
\hline treated & 102 & 0.2451 & 0.05107 \\
control & 93 & 0.5161 & 0.08596 \\
\hline
\end{tabular}

\section{CONCLUSION}

Although the declines of red elm bark weevil populations later in the season precluded a longer record of the effects of tree injection, the method was effective in delivering sufficient active ingredient to the target to reduce REBW numbers in the elm trees. The result was detectable even though treated and untreated trees were contiguous, typically on the same side of a paved lane. No phytotoxic effects were apparent. Future studies could be conducted to determine the dynamics of active ingredient concentrations in leaf and wood tissue, to compare the results of a range of rates, and to determine rates that would be required for economical and effective operational-scale control.

Acknowledgments. Funding, resources and personnel were provided by a Canadian TREE (Tree Research \& Education Endowment) Fund Jack Kimmel Grant in 2006, and by the Lethbridge Research Centre. Laboratory analysis and field assistance were provided by University of Lethbridge research staff, with the support of Canada Research Chairs. Sam Wind and Jenn Dorn assisted by assistance with sticky trap examination and spectrophotometric analysis, respectively. We thank the International Society of Arboriculture (ISA) Prairie Chapter for their support and encouragement.

\section{LITERATURE CITED}

Abbott, W.S. 1925. A method of computing the effectiveness of an insecticide. Journal of Economic Entomology 18:265-267.

Doccola, J., P.M. Wild, I. Ramasamy, P. Castillo, and C. Taylor. 2003. Efficacy of arborjet viper microinjections in the management of hemlock wooly adelgid. Journal of Arboriculture 29:327-330.

Doughty, S.C., D.K. Pollet, R.J. Constantin, D.W. Wells, and K.L. Koonce. 1992. Paint- on application of acephate for aphid control on crapemyrtle. Journal of Arboriculture 18:94-97.

Gill, S., D.K. Jefferson, R.M. Reeser and M.J. Raupp. 1999. Use of soil and trunk injection of systemic insecticides to control lace bug on hawthorn. Journal of Arborculture 25:38-42.

Health Canada, Pest Management Regulatory Agency. 2004. Re-evaluation of Acephate. PACR2004-40. 68 pp. Ottawa, Canada. www.pmraarla.gc.ca

Johnson, D.L., 1983. On the relationship between the European red mite and apple leaf chlorophyll. Journal of the Entomological Society of British Columbia 80:42-45.

Knudson, L.L., T.W. Tibbitts, and G.E. Edwards. 1977. Measurement of ozone injury by determination of leaf chlorophyll concentration. Plant Physiology 60:606-608.

SAS Institute, 2007. SAS Ver. 9.1 and JMP Ver. 5.1

Saunders, C., M.D. Wartenbe, and W.B. Barr. 2004. Drought stress problems in Edmonton's Forest. 6th Canadian Urban Forest Conference, Oct 18-23, 2004, Kelowna, BC. (www.treecanada.ca/cufc6/proceedings/papers/Saunders.pdf)

Schaalje, G.B., W.A. Charnetski, and D.L. Johnson. 1986. A comparison of estimators of the degree of insect control. Communications in Statistics: Simulations and Computations 15:1065-1086.

Tipping, P.W., and T.D. Center. 2002. Evaluating acephate for insecticide exclusion of Oxyops vitiosa (Coleoptera: Curculionidae) from Melaleuca quinquenervia. Florida Entomologist 85:458-463. 
Tucker, E.S. 1907. Concerning some insects collected and bred from dead and dying elm. Transactions of the Kansas Academy of Science 21:158-162.

Young, L.C. 2002. The efficacy of micro-injected imidacloprid and oxydemeton-methyl on Red Gum Eucalyptus trees (Eucalyptus camaldulensis) infested with red gum lerp psyllid (Glycaspis brimblecombei). Journal of Arboriculture 28:144-147.

Michael Booth (corresponding author)

Agriculture and Agri-Food Canada

Lethbridge Research Centre, 5403 - 1 Avenue S.

Lethbridge, $A B$, Canada

TIJ 4B1

BoothM@agr.gc.ca

Dan Johnson

University of Lethbridge

4401 University Drive

Lethbridge, $A B$, Canada

T1K $3 \mathrm{M} 4$

dan.johnson@uleth.ca

Résumé. Des variations communes de systèmes d'injection pressurisés (Ecoject System) ont été utilisées dans une expérience pour évaluer l'injection d'acephate dans des ormes (Ulmus americana) comme moyen de réduction de l'abondance du charançon de l'orme (Magdalis armicollis). Un total de 25 ormes ont été traités, chacun étant en pair avec un arbre non traité. Un total de 400 contenants pressurisés ont été employés dans l'étude. La densité de population de charançon de l'orme, telle qu'indiquée par un piège collant, ne différait significativement pas entre les arbres traités et ceux non traités. Deux semaines après l'injection, la moyenne de capture sur les arbres non traités avait augmenté tandis que la moyenne sur les arbres traités était significativement plus faible que pour les arbres témoins. Même si les déclins subséquents de populations de charançons ne pouvaient être testés sur une longue période, les apparentes diminutions significatives dans les deux premières semaines qui suivaient l'injection indiquaient que la méthode était efficace pour réduire l'abondance de charançons. L'impact sur les populations de charançons de l'orme était détectable même si les arbres traités et non traités étaient contigus, ce qui indique que le traitement sélectif d'arbres individuels peut être un moyen opérationnel effectif dans la gestion du cha- rançon. Aucun effet phytotoxique n'a été détecté au moyen d'évaluations spectrophotométriques de chlorophylle foliaire.

Zusammenfassung. In einem Experiment zur Reduzierung der Ausbreitung von Ulmenkäferlarven (REBW), Magdalis armicollis in Ulmen durch die Injektion von Acephat wurden tragbare druckhaltige Injektionseinheiten (Ecojet System) verwendet. Insgesamt wurden 25 Ulmen, jeweils mit einem unbehandelten Nachbarn, getestet. Insgesamt wurden 400 Druckbehälter in dieser Studie verwendet. Die REBW-Populationsdichte, wie sie zuvor durch Klebfallen bestimmt wurde, differierte zu Beginn der Studie nicht. Zwei Wochen nach der Behandlung stieg die Fangquote auf den Klebfallen bei den 25 unbehandelten Bäumen, während sie bei den behandelten Bäumen sank. Die durchschnittliche Fangquote bei den behandelten Bäumen war deutlich niedriger als bei den Kontrollbäumen. Obwohl die subsequente Reduzierung der REBW-Population eine längere Kontrolle der Auswirkungen der Injektionen ausschließt, ist doch die signifikante Reduktion in den ersten zwei Wochen nach der Applikation ein Zeichen dafür, dass die Methode effektiv ist. Der Einfluss auf die REBW-Population war trotz der engen Nachbarschaft behandelter und unbehandelter Bäume nachweisbar. Das zeigt, dass eine individuelle Behandlung Teil einer effektiven REBW-Kontrolle sein kann. Bei einer spektrometrischen Untersuchung des Chlorophylls konnten keine phytotoxischen Effekte beobachtet werden.

Resumen. Se utilizaron inyecciones portables presurizadas (Ecoject System) en un experimento para evaluar inyecciones de acefato en árboles de olmo (Ulmus americana) como un medio para reducir la abundancia del escarabajo rojo del olmo dentro del árbol (REBW, por sus siglas en inglés), Magdalis armicollis. Se trató un total de 25 olmos, cada uno con otro no tratado. Se emplearon un total de 400 botes en el estudio. La densidad de la población de REBW, como se indicó en trampas de papel, en árboles tratados y no tratados no difirió significativamente en la inyección al tronco. Dos semanas después de la inyección, el promedio de REBW atrapados en los 25 árboles no tratados había incrementado, mientras que el promedio de los atrapados en los 25 árboles tratados había disminuido. El promedio resultante de los atrapados en los árboles tratados fue significativamente menor que los árboles de control. Sin embargo, la subsecuente declinación en las poblaciones de REBW concluye un efecto prolongado de las inyecciones. Las aparentes significantes reducciones en las primeras dos semanas después de la inyección indicaron que el método fue efectivo en reducir la abundancia de REBW. El impacto en las poblaciones de REBW fue detectable aun en los casos en que los árboles tratados y no tratados eran contiguos, indicando que el tratamiento selectivo de árboles individuales podría ser parte de un tratamiento operacional efectivo para el manejo de REBW. Mediante evaluaciones espectrométricas no se detectaron efectos fitotóxicos de la clorofila foliar. 